\title{
Evaluation of groundwater recharge in Poland using the infiltration coefficient method
}

\author{
Robert TARKA ${ }^{1}$, Tomasz OLICHWER ${ }^{1, *}$ and Stanisław STAŚKO ${ }^{1}$ \\ 1 Wrocław University, Institute of Geological Sciences, M. Borna sq. 9, 50-204 Wrocław, Poland
}

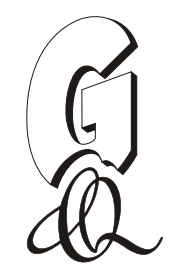

Tarka, R., Olichwer, T., Staśko, S., 2017. Evaluation of groundwater recharge in Poland using the infiltration coefficient method. Geological Quarterly, 61 (2): 384-395, doi: 10.7306/gq.1341

\begin{abstract}
Variable methods and results are reported on groundwater recharge in Poland. The evaluation of recharge on a small scale requires the use of a single method. In order to evaluate these outcomes and their distribution, the authors have decided to verify different approaches and select the infiltration coefficient by comparison. The article is an extension of the studies on groundwater recharge conducted by the authors. The main goal is to verify previously designed values of the infiltration coefficient based on groundwater runoff from additional river basins in Poland. Total groundwater recharge from precipitation in Poland was calculated at $34,118 \mathrm{~km}^{3}$ per year, which equals $109.3 \mathrm{~mm}$ of water column. The obtained value is close to the average multi-year value of the groundwater runoff. Recharge constituted $18.6 \%$ of average precipitation in Poland, which was calculated at $588.5 \mathrm{~mm}$. The estimated groundwater recharge value was verified referring to groundwater runoff from 37 river basins with known discharge rates in the years 1976-2005. Differences in mean groundwater runoff for the entire area (37 river basins) obtained by the infiltration coefficient method and by the use of Wundt's method amounts to only $0.7 \%$. Despite the simplified calculation methods, the results obtained on a small scale are more accurate than other calculations, which are based on data pertaining to precipitation, soil type, land use, topography of the area, and depth to the groundwater.
\end{abstract}

Key words: groundwater recharge, infiltration coefficient, Poland.

\section{INTRODUCTION}

The article is an extension of the studies on groundwater recharge described by Staśko et al. (2012). At that stage, soil maps at a scale of 1:500,000 were selected to estimate groundwater recharge by the infiltration coefficient method for regional evaluation. Based on measured value of groundwater runoff and rock types, the infiltration coefficient (recharge rate) was defined for selected soil types. Next, in designated 15 test river basins from Lower Silesia (SW Poland), the recharge rate was calculated as a groundwater-related runoff associated with the catchment area.

The main goal of this paper is to verify previously designed values of the infiltration coefficient based on groundwater runoff from additional river basins of Poland. In total, 37 river basins, with a long-term and uniform river flow database, have been evaluated. Result of the previous study allows more correct evaluation of the recharge value associated with the precipitation distribution in the same way for the whole country. The results have been compared with selected outcomes from numerical modelling and reported values in Poland and other countries.

Groundwater recharge is an indicator of groundwater resources. It has a direct impact on the size of groundwater re-

\footnotetext{
* Corresponding author, e-mail: tomasz.olichwer@uwr.edu.pl
}

Received: March 21, 2016; accepted: July 26, 2016; first published online: January 20, 2017 newable resources and, to a large extent, determines the degree of groundwater vulnerability to contamination. Due to the high variability of physical and climatic conditions in Poland, many different methods have been employed in order to assess the recharge of particular river basins. However, the evaluation of recharge on a smaller scale, such as that of the whole country or large river basins, requires the use of a single method. For this reason, the authors have decided to assess groundwater recharge in a general scale for the whole area of Poland using the infiltration coefficient method.

While developing the methods of evaluating groundwater recharge, it is necessary to include processes occurring in the unsaturated and saturated zones and take into account areal and linear recharge, as well as recharge in preferential zones. They also comprise methods of evaluating groundwater runoff as the final stage of recharge. These methods can be divided into several groups: water balance, lysimeter, isotope tracking, numerical modelling, heat transfer, groundwater table fluctuation, and river hydrograph separation. The benefits and drawbacks of each of these techniques are analysed by Pazdro and Kozerski (1990), de Vries and Simmers (2002), Scanlon et al. (2002), and Brodie and Hostetler (2005).

Water balance methods require not only the knowledge of the changeability of precipitation, but also the evaluation of evapotranspiration, which adds to difficulties. Lysimeter methods are expensive experiments that allow for precise calculations in shallow zones. Isotope and heat transfer methods are more reliable on a local, rather than a regional scale. The groundwater table fluctuation method, despite numerous and 
lengthy observations, relies heavily on the assumption that the parameters of aquifers are constant. Numerical modelling tests, based on the theory of water-bearing systems, are a useful tool when conducting experiments on a regional scale. Separation of river hydrographs illustrates the final result of effective infiltration and recharge along with its regional variability and is considered the most representative on a regional scale.

The majority of these techniques have been used in Poland, especially the water balance method. The isotope technique has also been implemented, albeit to a smaller extent (e.g., Pleczyński, 1981). The method most frequently employed when documenting groundwater resources is the water balance and effective infiltration method, which is mainly based on the permeability of surface formations (Pazdro and Kozerski, 1990 Paczyński, 1995). This method does not take into account the water capacity of rock formations. Methods based on the results of long-term pumping tests and the increasingly popular results of numerical modelling dominate in cartographic records.

An efficient way of evaluating the groundwater renewable resources is determining effective infiltration by means of the infiltration coefficient. This approach assumes that a portion of precipitation reaches aquifers and then is discharged through subterranean outlets into springs, rivers, lakes or the sea. The volume of water seeping to water-bearing layers is defined by means of an effective infiltration coefficient showing the ratio of effectively infiltrated water table to the arithmetic mean of annual rainfall measured over a number of years. The result is given either in percentage or decimal fractions. In Poland, the infiltration coefficient method was generally used in lowlands (Pazdro and Kozerski, 1990). However, attempts were also made to employ this method in uplands (Tarka, 2001) and mountainous areas (Duda et al., 2006).

\section{STUDY AREA}

The study is located in the eastern part of the North European Plain, dominated by lowlands markedly sloping down from south-east to north-west, with an average elevation of $173 \mathrm{~m}$ (Fig. 1). Lowlands (<300 $\mathrm{m}$ above sea level) take up around $91.3 \%$ of the total area of Poland, with highlands (between $300 \mathrm{~m}$ and $500 \mathrm{~m}$ ) and mountainous areas (above 500 metres above sea level) constituting, respectively, $5.6 \%$ and $3.1 \%$ of the total area (Kondracki, 1994). The average annual rainfall for the whole country is around $600 \mathrm{~mm}$, although precipitation depends strongly on the elevation. For lowlands and highlands, for example, the figures range from 450 to $750 \mathrm{~mm}$, while in mountainous areas, precipitation as high as $1200-1500 \mathrm{~mm}$ can be expected (Kondracki, 1994). The rainfall peaks during the summer months.

The Sudetes and Carpathians dominate the landscape of southern Poland. The erosive and accumulative activity of Pleistocene glaciers and ice sheets during the Quaternary period had a significant impact on the geological structure of surface layers in central and northern Poland. Four glacials interspersed with interglacials have lead to the accumulation of compact glacial drifts such as sand, gravel or clay, whose thickness reaches 150-200 $\mathrm{m}$ in some places (Stankowski, 1996). These deposits contain about $75 \%$ of renewable groundwater resources of Poland (Fig. 2). Groundwater in Quaternary deposits occurs in several layers, whose number and thickness increases from the south to the north of Poland. The water is accumulated in porous material such as sand and clay sediments, which are the most common aquifers in central and northern Poland. The occurrence of groundwater in the highlands and the West Tatra Montains is strictly connected to the formation of

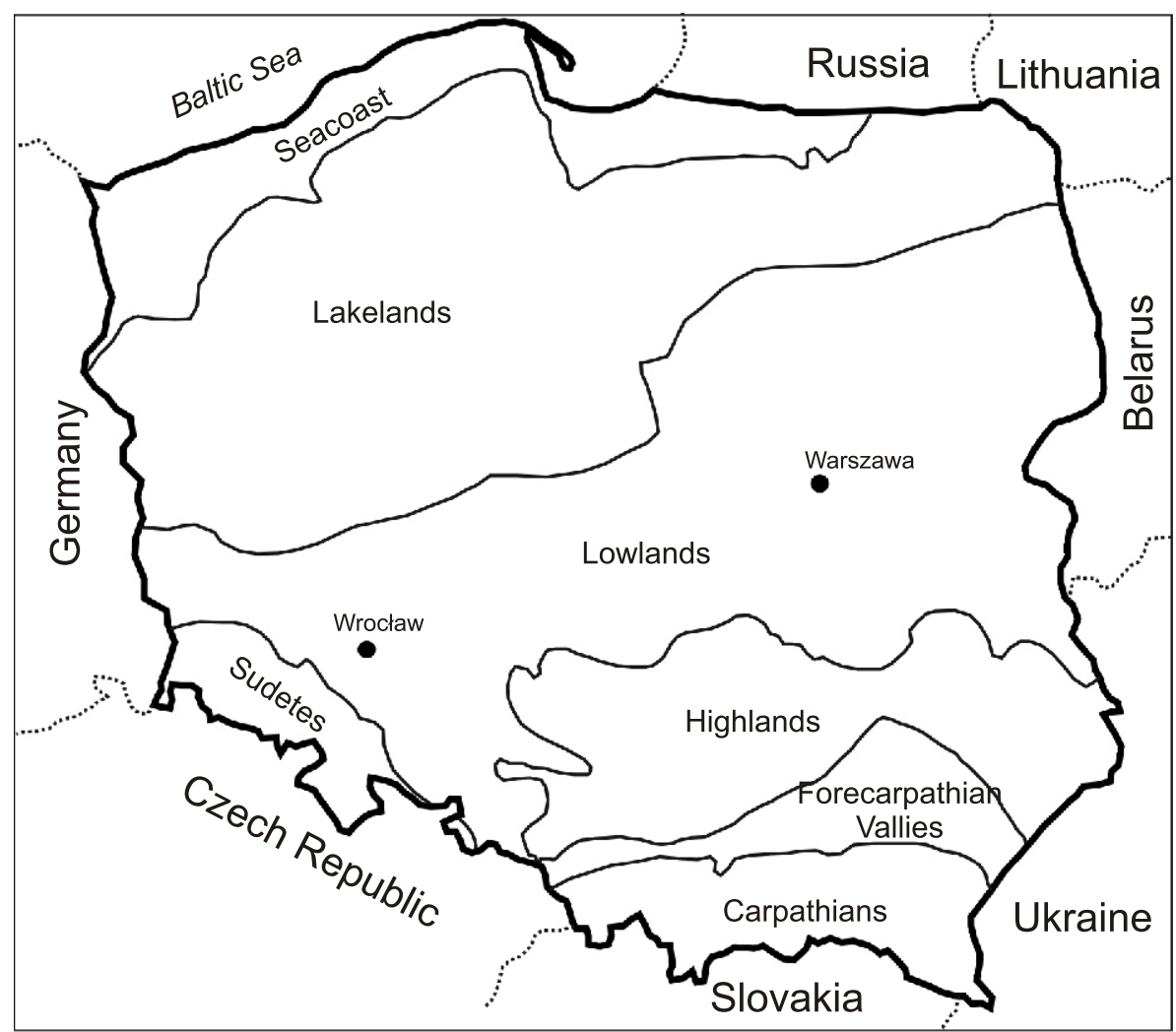

Fig. 1. General overview map of Poland 


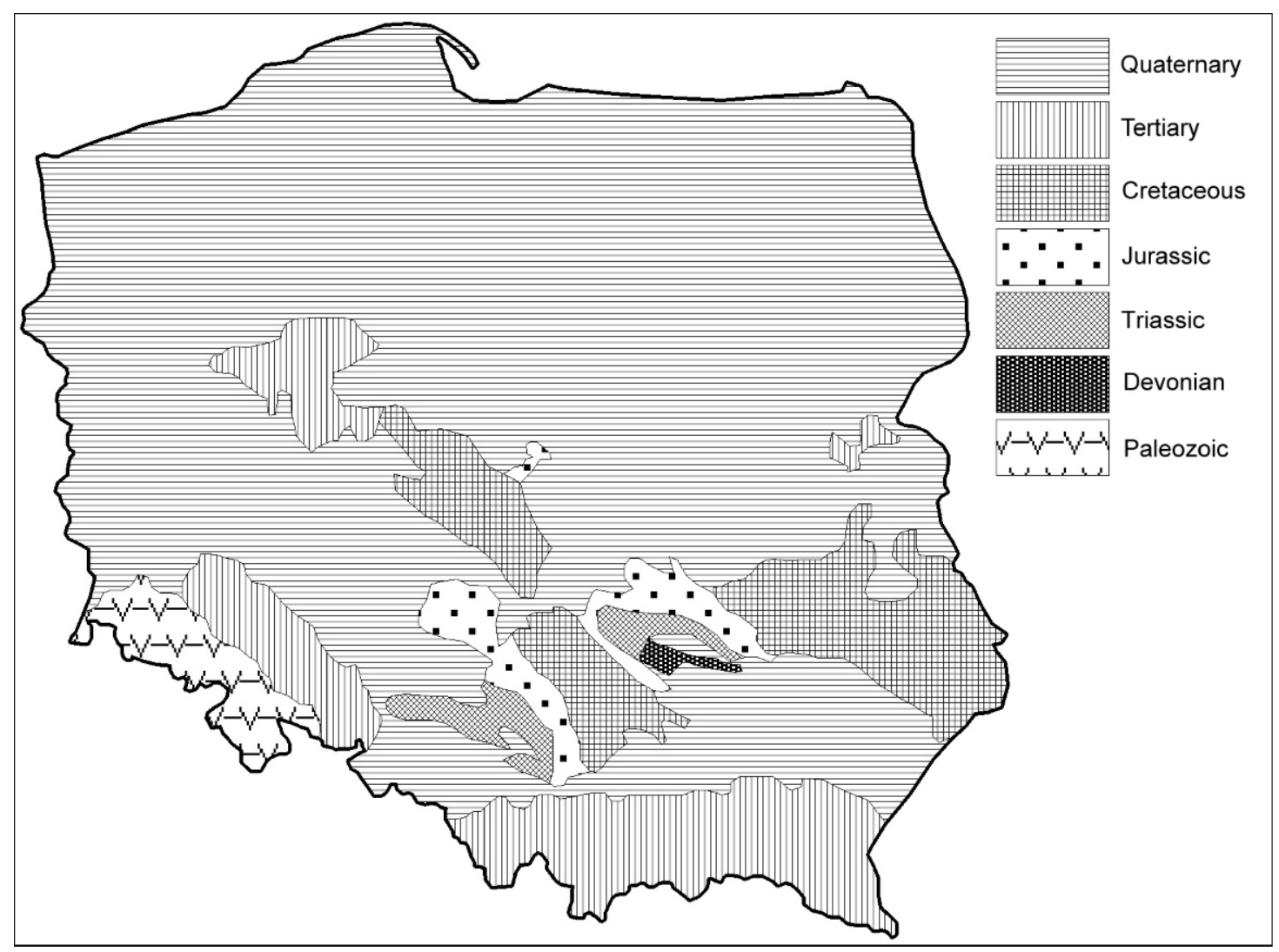

Fig. 2. A schematic map of the first aquifer formation in Poland (after Paczyński, 1995)

fracture-karstic reservoirs by carbonate structures. In the Sudetes area, groundwater is mostly linked with fractured crystalline formations and their granular weathering cover.

The groundwater table usually occurs within the uppermost aquifer that can be found at varying depths depending on the location. In carbonate-rich highlands, these aquifers usually lie at depths of 10-50 m. In the Carpathians, Sudetes and in terminal moraine areas of the lake district in northern Poland, they can be found at depths of up to $20 \mathrm{~m}$. In the central lowlands and Forecarpathian Vallies, the depth, at which these aquifers are located, usually does not exceed $5 \mathrm{~m}$ (Paczyński and Sadurski, 2007).

In order to evaluate the groundwater recharge map of Poland, 37 river basins from all over Poland have been selected. The river basins 1-15 are located in Lower Silesia (test area stage II). Next 22 river basins (16-37, test area - stage III) have been selected from the remaining part of Poland (Table 1 and Fig. 3).

A more detailed hydrogeological description of the 37 river basins and the verification of the calculations of groundwater recharge are illustrated in Table 1. The river basins (Fig. 3) differ between each other in their surface areas and locations relative to physical, geographical and hydrogeological units, and cover a total area of $50,737 \mathrm{~km}^{2}$.

\section{METHODS AND MATERIALS}

An efficient way of evaluating the renewable groundwater resources is determining effective infiltration by means of the infiltration coefficient. This approach assumes that a portion of precipitation reaches aquifers and then is discharged through subterranean outlets into springs, rivers, lakes or the sea. The volume of water seeping to water-bearing layers is defined by means of an infiltration coefficient method.

The infiltration of precipitation in an area can be computed by referring to geological or soil maps. Thus, the test areas have to be identified on the map and assigned to separate infiltration classes. There are several classifications used for the assigning, e.g. classifications by Paczyński (1972), Schneider and Züschang (Załuski, 1973), Wright et al. (1982), Pazdro and Kozerski (1990), Daly (1994), Singh (2003), Voudouris et al. (2007) and Ali Rahmani et al. (2016). In these classifications the infiltration coefficient of very good permeable rocks (fluvioglacial and aeolian sands and gravel, fractured and karst rocks) ranges from 0.3 to 0.5 , and for good and medium permeable deposits (sands and gravel in terminal moraines, glacial sands and gravel, sands and muds, alluvial fill terraces, diluvial sands, peat, silty sands) it is $0.2-0.25$. The lowest figures $<0.1$ are typical for tills, loams, stagnant-river/lake muds, diluvial clays, non-fractured clay rocks, phyllites, limestones, sandstones, shales and hard rocks. The infiltration coefficient value is associated not only with the permeability of the soil/rock in the unsaturated zone, but also with the climatic zonation. For example, Ali Rahmani et al. (2016) reported these values for the semi-arid condition.

The lithological maps and knowledge of precipitation levels is necessary to calculate effective infiltration. Large-scale geological maps, which depict various types of surface cover, are useful when creating lithological maps. When conducting research on a smaller scale or whole country, lithological maps must be generalized or substituted with other available sources, such as small-scale geological maps. Soil maps are also suitable for determining the infiltration coefficient, since the type 
Hydrogeological characteristics of the river basins

\begin{tabular}{|c|c|c|c|c|c|c|}
\hline No. & River/gauge & $\begin{array}{l}\text { Surface } \\
\text { area } \\
{\left[\mathrm{km}^{2}\right]}\end{array}$ & $\begin{array}{l}\text { Precipi- } \\
\text { tation } \\
\text { [mm] }\end{array}$ & Type of aquifer & Aquifer stratigraphy & $\begin{array}{l}\text { Depth to groundwater } \\
\text { table/type of groundwater } \\
\text { flow }\end{array}$ \\
\hline 1 & Orla/Korzeńsko & 1141 & 525 & porous & Quaternary & 0-10/confined, unconfined \\
\hline 2 & Barycz/Osetno & 4589 & 533 & porous & Quaternary & 2-10/confined, unconfined \\
\hline 3 & Mała Panew/Staniszcze Wlk. & 1068 & 637 & $\begin{array}{l}\text { porous, frac- } \\
\text { tured-karstic }\end{array}$ & Quaternary, Triassic & 5-15/confined, unconfined \\
\hline 4 & Biała/Dobra & 358 & 625 & porous & $\begin{array}{l}\text { Quaternary, } \\
\text { Paleogene }\end{array}$ & 0-10/confined, unconfined \\
\hline 5 & Biała Lądecka/Lądek Zdrój & 161 & 846 & fractured & Paleozoic & 5-30/confined, unconfined \\
\hline 6 & Bystrzyca Dusznica/Szalejów DIn. & 174 & 742 & porous-fractured & Cretaceous & 5-40/confined, unconfined \\
\hline 7 & Nysa Kłodzka/Kłodzko & 1060 & 622 & $\begin{array}{c}\text { porous, } \\
\text { porous-fractured, } \\
\text { fractured }\end{array}$ & $\begin{array}{l}\text { Quaternary, Creta- } \\
\text { ceous, Paleozoic }\end{array}$ & 0-40/confined, unconfined \\
\hline 8 & Nysa Kłodzka/Skorogoszcz & 3927 & 614 & $\begin{array}{l}\text { porous, } \\
\text { porous-fractured, } \\
\text { fractured }\end{array}$ & $\begin{array}{c}\text { Quaternary, } \\
\text { Paleogene, Creta- } \\
\text { ceous, Triassic, } \\
\text { Permian, Paleozoic }\end{array}$ & 0-40/confined, unconfined \\
\hline 9 & Oława/Oława & 961 & 577 & porous, fractured & $\begin{array}{c}\text { Quaternary, Paleo- } \\
\text { zoic }\end{array}$ & 0-40/confined, unconfined \\
\hline 10 & Ślęza/Białobierze & 186 & 575 & porous & $\begin{array}{l}\text { Quaternary, } \\
\text { Paleogene }\end{array}$ & 0-10/confined, unconfined \\
\hline 11 & Bystrzyca/Jugowice & 120 & 622 & fractured & Paleozoic & 5-30/confined, unconfined \\
\hline 12 & Bystrzyca/Krasków & 678 & 585 & porous & $\begin{array}{l}\text { Quaternary, } \\
\text { Paleogene }\end{array}$ & $0-10 /$ confined, unconfined \\
\hline 13 & Kaczawa/Świerzawa & 136 & 575 & $\begin{array}{c}\text { fractured, } \\
\text { fractured-karstic }\end{array}$ & Paleozoic & 5-30/confined, unconfined \\
\hline 14 & Czarny Potok/Mirsk & 51 & 725 & fractured & Paleozoic & 5-30/confined, unconfined \\
\hline 15 & Bóbr/Żagań & 4258 & 605 & $\begin{array}{l}\text { porous, po- } \\
\text { rous-fractured, frac- } \\
\text { tured }\end{array}$ & $\begin{array}{l}\text { Quaternary, Creta- } \\
\text { ceous, Paleozoic }\end{array}$ & 0-40/confined, unconfined \\
\hline 16 & Gwda/Piła & 4697 & 605 & porous & Quaternary & 2-10/confined, unconfined \\
\hline 17 & Drawa/Drawsko Pomorskie & 609 & 673 & porous & Quaternary & 2-10/confined, unconfined \\
\hline 18 & Ina/Goleniów & 2127 & 573 & porous & Quaternary & 2-10/confined, unconfined \\
\hline 19 & Słupia/Słupsk & 1428 & 674 & porous & Quaternary & 5-15/confined, unconfined \\
\hline 20 & Warta/Działoszyn & 4092 & 608 & $\begin{array}{l}\text { fractured-karstic, } \\
\text { porous-fractured }\end{array}$ & Jurassic & 5-20/confined, unconfined \\
\hline 21 & Prosna/Mirków & 1249 & 579 & porous & Quaternary & 5-15/confined, unconfined \\
\hline 22 & Noteć/Pakość & 2174 & 525 & porous & Quaternary & 2-20/confined, unconfined \\
\hline 23 & Reda/Wejherowo & 393 & 670 & porous & Quaternary & 5-10/confined, unconfined \\
\hline 24 & Bukowa/Ruda Jastkowska & 650 & 581 & porous & Quaternary & 5-0/confined, unconfined \\
\hline 25 & Pisa/ptaki & 355 & 615 & porous & Quaternary & 5-10/confined, unconfined \\
\hline 26 & Liwiec/Łochów & 246 & 525 & porous & Quaternary & 20/confined, \\
\hline 27 & Biała/Grybów & 205 & 736 & porous-fractured & Paleogene & 8-20/confined \\
\hline 28 & Skawa/Jordanów & 98 & 950 & porous-fractured & $\begin{array}{l}\text { Paleogene, Creta- } \\
\text { ceous }\end{array}$ & 8-20/confined \\
\hline 29 & Łososia/Piekiełko & 154 & 810 & porous-fractured & Paleogene & 8-20/confined \\
\hline 30 & Skrwa/Parzeń & 154 & 525 & porous & Quaternary & 5-10/confined, unconfined \\
\hline 31 & Kamienica/Nowy Sącz & 237 & 698 & porous-fractured & Paleogene & $8-20 /$ confined \\
\hline 32 & Świder/Wólka Mlądzka & 835 & 525 & porous & Quaternary & 5-10/confined, unconfined \\
\hline 33 & Orzyc/Krasnosielsk & 1275 & 568 & porous & $\begin{array}{l}\text { Quaternary, } \\
\text { Paleogene }\end{array}$ & 8-20/confined \\
\hline 34 & Brzozówka/Karpowicze & 650 & 575 & porous & Quaternary & 5-10/confined, unconfined \\
\hline 35 & Nurzec/Boćki & 546 & 525 & porous & Quaternary & 5-10/confined, unconfined \\
\hline 36 & Wierzyca/Bożepole Szlacheckie & 404 & 588 & porous & Quaternary & 5-10/confined, unconfined \\
\hline 37 & Pilica/Przedbórz & 2457 & 605 & karstic-fractured & Triassic & 0-5/unconfined \\
\hline
\end{tabular}




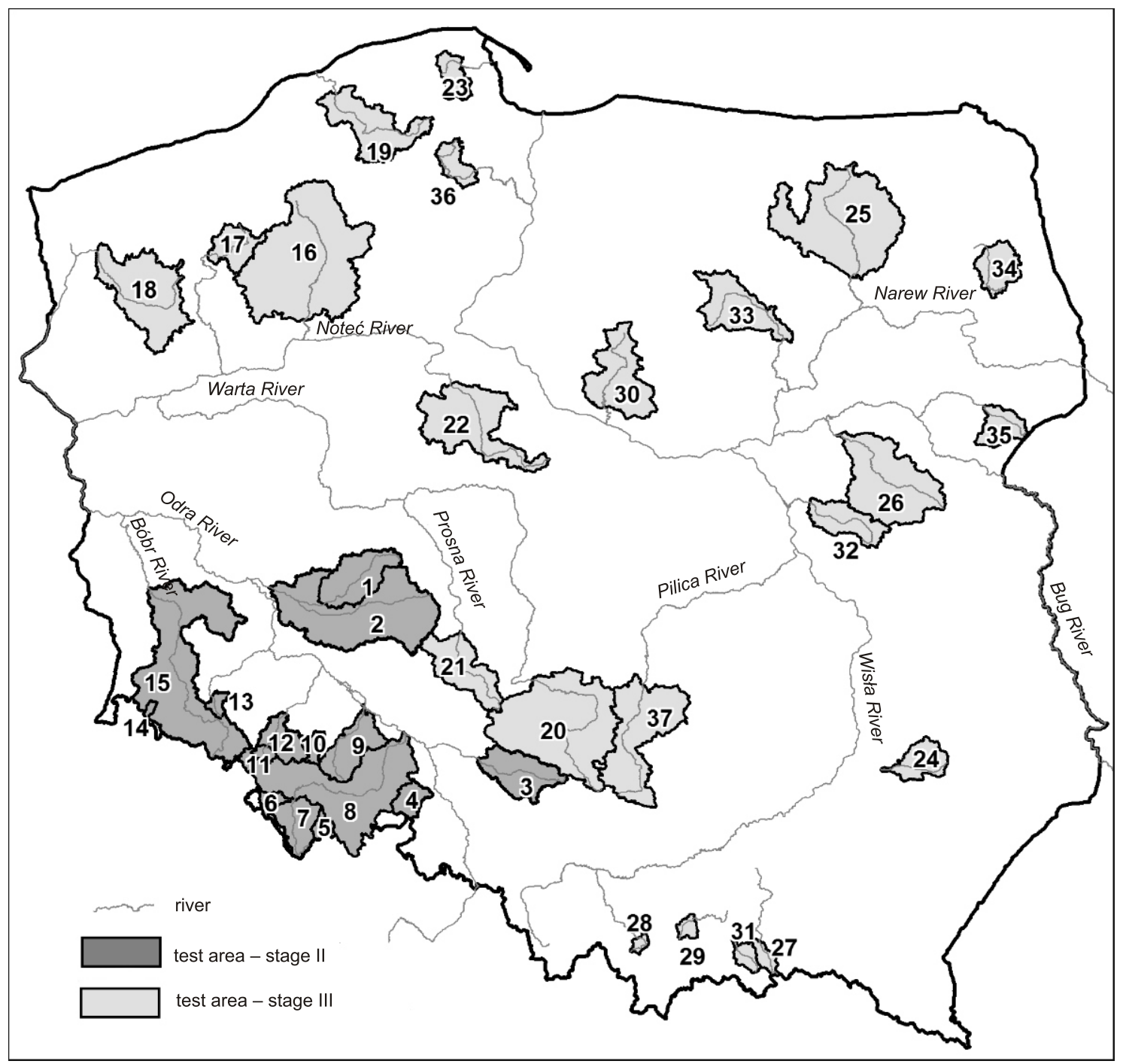

Fig. 3. Location of river basins (numbers as in Table 1)

and category of soil reflects the geological structure and climatic conditions. There is also a direct correlation between the lithological form and the grain-size group of the co-occurring soil. This correlation was relied upon in the process of drawing up guidelines for data compilation for "The map of groundwater vulnerability to pollution in Poland" at a scale of $1: 500,000$ (Duda et al., 2011).

The assessment of groundwater renewable resources by means of the infiltration coefficient method requires the division of a given area into regions with varying average annual precipitation levels. They can be selected, for example, by looking at isohyets. Next, the area of each class reflecting infiltration coefficients in a given precipitation zone must be defined. This forms a basis for calculating the weighted mean [1] of the infiltration coefficient for each precipitation area.

$$
\alpha_{r}=\frac{\sum_{i=1}^{n} \alpha_{i} \times A_{i}}{\sum_{i=1}^{n} A_{i}}
$$

where: $\alpha_{r}-$ the average infiltration coefficient for precipitation zone (effective fraction), $r, \alpha_{i}-$ the infiltration coefficient for the $i$-lithological configuration within the precipitation zone, $A_{i}$ - the surface of the $i$-lithological configuration $\left[\mathrm{L}^{2}\right]$ in precipitation zone $r$.

The aggregate recharge [2] is the sum of recharge values calculated for each precipitation area:

$$
R=\frac{\sum_{r=1}^{m} \alpha_{r} \times P_{r} \times A_{r}}{A}
$$

where: $R$-groundwater recharge, $P_{r}$ - the average annual rainfall in precipitation area $r[\mathrm{~L}], A-$ the area under study $\left[\mathrm{L}^{2}\right], m-$ the number of selected precipitation zones.

This method for determining groundwater recharge has been used to calculate the total recharge in Poland by authors.

It is worth mentioning that groundwater recharge depends not only on the amount of precipitation, but also on air temperature, depth to the groundwater table, and plant cover. Hence, when making calculations, e.g. for mountainous areas, infiltration coefficients should include the relationships with climatic conditions affecting the percentage increase in infiltration. An example is the methods used to estimate an effective infiltration in the 
framework of the Hydrogeolgical Map of Poland 1:50,000 (Herbich et al., 2008) and the map of groundwater vulnerability to pollution in Poland 1:500,000 (Duda et al., 2011). Intensity of groundwater recharging by infiltration was evaluated by superposition of current information pertaining to precipitation, soil type, land use, topography of the area, and depth to groundwater.

The groundwater recharge for Poland has been estimated in three stages. Stage I - selection of methods, stage II - test of the methods in Lower Silesia and compilation of a map of groundwater recharge for the whole of Poland, stage III checking the map in particular 22 areas.

The selection of methodology to determine the groundwater recharge on a general scale has been done in first step. The creation of a comprehensive map of groundwater recharge in Poland in general scale required the identification of particular infiltration classes. This was done through the use of the infiltration coefficient method and with the help of a numerical soil map (a scale of 1:500,000), created by the Institute of Soil Science and Plant Cultivation in Puławy. Precipitation was determined according to the "Polish Climate Atlas" (Lorenc, 2005).

During the first stage, infiltration coefficients for given soil class (Table 2) were determined according to the principles used in the construction of the soil profile's protective layer of map of groundwater vulnerability to pollution in Poland (Duda et al., 2011; Table 2).

In the second stage, verification of the methods has been evaluated based on selected rivers with long-term measurements in Lower Silesia (SW Poland), where, as a result, a positive correlation was approved (Staśko et al., 2012). Recharge values were first calculated for the test areas which covered river basins near the upper and central Odra River basin. Calculations have been made for 15 river basins (test area - stage II; Fig. 3), differing from each other in surface area and location relative to physical, geographical and hydrogeological units, and covered in aggregate an area of $17,000 \mathrm{~km}^{2}$. The recharge was assessed according to the previously described method [formulas 1 and 2]. The estimated groundwater recharge value was verified referring to groundwater runoff from the river basins under study. Wundt's method (Wundt, 1953; Jokiel, 1994) was applied to calculate groundwater runoff from the catchments during the years 1976-2005. According to Wundt (1953) the mean monthly low water runoff yield corresponds for long observation periods to the groundwater runoff of a catchment area and consequently to the groundwater recharge. However, the recharge figures obtained through the use of the infiltration coefficient were incompatible to these of the groundwater runoff from the areas under study. In order to correct this, both the figure for the infiltration coefficient and soil classes had to be modified. Results of several analyses prompted the decision to change the infiltration coefficient for "very light soil" from 27 to $30 \%$. It was also agreed that forest areas (Ls) with low soil thickness, previously classified as "medium soil", should in fact fall into the "light soil" category. This resulted in the infiltration coefficient values for these areas having to be changed from 13 to $20 \%$.

The final result of the second stage is a map of groundwater recharge for the whole of Poland.

In the third stage the reliability of the map was checked in particular 22 areas (test area - stage III). Detailed calculations were made for 22 river basins (whole Poland) with measured river flows in the years 1976-2005 (Fig. 3). Wundt's method was applied to calculate groundwater runoff from the catchments.

Additional two statistical indicators have been applied to evaluate precision of the designed value of recharge and groundwater runoff. The first means the quotient of the module of the difference among the calculated values with the infiltration method $(\mathrm{R})$ and the groundwater runoff $(\mathrm{Qg})$ and groundwater runoff expressed in $\%$ [100\%(R-Qg) $/ / \mathrm{Qg}]$. This value is expressed as AV (absolute variability). The second one, specific difference (SD), is a quotient of the difference among the calculated recharge values evaluated by an infiltration method and groundwater runoff and the area of the river basin $\left[(\mathrm{R}-\mathrm{Qg}) / \mathrm{A}\right.$. It is expressed in $\mathrm{l} / \mathrm{s} \sim \mathrm{km}^{2}$.

\section{RESULTS AND DISCUSSION}

Results of groundwater recharge acquired based on the revised infiltration coefficients (stage II - Methods) for the 15 river basins (Lower Silesia) were compared with the groundwater runoff recorded in these basins. Infiltration values calculated based

Protective capacities of soil (vide Duda et al., 2011)

\begin{tabular}{|l|c|c|c|c|c|}
\hline $\begin{array}{c}\text { Soil protective } \\
\text { capacity }\end{array}$ & Soil category & Soil type acc. to grain size group & $\begin{array}{c}\text { Infiltration } \\
\text { coefficient } \\
{[\%]}\end{array}$ & $\begin{array}{c}\text { Water ca- } \\
\text { pacity }{ }^{\text {a) }} \\
{[-]}\end{array}$ & $\begin{array}{c}\text { tg1m approximate time of water } \\
\text { exchange in } 1 \mathrm{~m} \text { of soil profile } \\
\text { [years] }\end{array}$ \\
\hline Very weak & very light & $\begin{array}{c}\text { gravel soils, loose sands, slightly } \\
\text { clayey sands, rocky soils, skeletal } \\
\text { soils, sandy soils }\end{array}$ & $30\left(27^{\star}\right)$ & 0.12 & 1.2 \\
\hline Weak & light & $\begin{array}{c}\text { clayey sands, slightly clayey and } \\
\text { clayey sands, Neogene rendzina } \\
\text { soils, Jurassic rendzina soils, } \\
\text { old-formation rendzinas, gypsum } \\
\text { rendzina soils, sandy alluvial soils, } \\
\text { muck and muck-like soils }\end{array}$ & 20 & 0.17 & 1.7 \\
\hline Medium & medium & $\begin{array}{c}\text { slightly clayey soils, silt soils, loess } \\
\text { and loess-like soils, clay soils, pow- } \\
\text { dery soils, Cretaceous rendzina } \\
\text { soils, alluvial soils }\end{array}$ & $13\left(20^{*}\right)$ & 0.24 & 2.4 \\
\hline Good & heavy & $\begin{array}{c}\text { clay: medium and powdery, heavy } \\
\text { and powdery, silt loam, peat, silts } \\
\text { and bog soils }\end{array}$ & 8 & 0.36 & 3.6 \\
\hline
\end{tabular}

a - average water capacity (natural volume of soil moisture); b - approximate time of water exchange was calculated for the average effective infiltration equal to $100 \mathrm{~mm}$ per year and based on the piston displacement model; $\left(27^{\star}\right)$ value modified by authors 
Comparison of evaluated effective infiltration and groundwater runoff in selected river basins of Lower Silesia (test area - stage II)

\begin{tabular}{|c|c|c|c|c|c|c|c|}
\hline No. & River & Gauge & $\begin{array}{c}\text { Calculated } \\
\text { infiltration } \\
{\left[\mathrm{m}^{3} / \mathrm{s}\right]}\end{array}$ & $\begin{array}{c}\text { Groundwater } \\
\text { runoff } \\
{\left[\mathrm{m}^{3} / \mathrm{s}\right]}\end{array}$ & $\begin{array}{c}\text { Differences } \\
{\left[\mathrm{m}^{3} / \mathrm{s}\right]}\end{array}$ & $\begin{array}{c}\text { Absolute } \\
\text { variability } \\
{[\%]}\end{array}$ & $\begin{array}{c}\text { Infiltration } \\
\text { coefficient } \\
{[\%]}\end{array}$ \\
\hline 1 & Orla & Korzeńsko & 3.08 & 1.76 & 1.32 & 75.0 & 16.2 \\
\hline 2 & Barycz & Osetno & 15.54 & 7.52 & 8.02 & 106.6 & 20.0 \\
\hline 3 & Mała Panew & Staniszcze Wlk. & 4.78 & 4.03 & 0.75 & 18.6 & 22.1 \\
\hline 4 & Biała & Dobra & 1.16 & 0.68 & 0.48 & 70.6 & 16.3 \\
\hline 5 & Biała Lądecka & Lądek Zdrój & 0.97 & 2.03 & -1.36 & 67.0 & 20.2 \\
\hline 6 & Bystrzyca Dusznicka & Szalejów Dln. & 0.67 & 1.3 & -0.63 & 48.5 & 18.9 \\
\hline 7 & Nysa Kłodzka & Kłodzko & 3.78 & 6.82 & -3.04 & 44.6 & 18.1 \\
\hline 8 & Nysa Kłodzka & Skorogoszcz & 15 & 17.31 & -2.31 & 13.3 & 19.6 \\
\hline 9 & Oława & Oława & 2.09 & 2.51 & -0.42 & 16.7 & 11.9 \\
\hline 10 & Ślęza & Białobierze & 0.52 & 0.24 & 0.28 & 116.7 & 15.3 \\
\hline 11 & Bystrzyca & Jugowice & 0.46 & 0.52 & -0.06 & 11.5 & 19.3 \\
\hline 12 & Bystrzyca & Krasków & 2.17 & 1.61 & 0.56 & 34.8 & 17.3 \\
\hline 13 & Kaczawa & Świerzawa & 0.4 & 0.6 & -0.20 & 33.3 & 16.1 \\
\hline 14 & Czarny Potok & Mirsk & 0.24 & 0.35 & -0.11 & 31.4 & 20.3 \\
\hline 15 & Bóbr & Żagań & 16.41 & 23.14 & -6.73 & 29.1 & 20.1 \\
\hline
\end{tabular}

on the infiltration coefficient method and those obtained usingWundt's method differ from each other by anywhere between $-0.06 \mathrm{~m}^{3} / \mathrm{s}$ and $8.02 \mathrm{~m}^{3} / \mathrm{s}$ (Table 3). These discrepancies are a result of imprecise estimations of precipitation levels, which, in the uppermost regions of the Sudetes, are significantly higher than what the rates used for calculations might suggest. The Barycz River basin also appears to behave in an unusual manner, probably due to changes in its natural environment and the influence of pond management on runoff conditions.

The mean precipitation level in the tested area equalled $587 \mathrm{~mm}$, while the average recharge, calculated through the infiltration coefficient method, was $109 \mathrm{~mm}$. This means that recharge constituted $18.5 \%$ of precipitation. Calculations based on groundwater runoff yielded a similar result: $108 \mathrm{~mm}$. In the whole Lower Silesia test area, the difference between recharge values calculated through the use of the infiltration coefficient and those based on groundwater runoff is only $0.7 \%$ (Staśko et al., 2012). This means that the values of groundwater recharge can be considered reliable on a regional scale.

The compatibility of groundwater runoff determined using the infiltration coefficient method in 15 river basins allowed for the creation of a map of groundwater recharge that would cover the whole area of Poland. Table 4 shows the portion of the area of Poland taken up by particular classes of infiltration. Figures

Table 4

Infiltration classes in Poland

\begin{tabular}{|l|c|c|c|}
\hline $\begin{array}{c}\text { Conditions } \\
\text { of infiltration }\end{array}$ & $\begin{array}{c}\text { Infiltration } \\
\text { coefficient } \\
{[\%]}\end{array}$ & $\begin{array}{c}\text { Area } \\
{\left[\mathrm{km}^{2}\right]}\end{array}$ & $\begin{array}{c}\text { Percentage of to- } \\
\text { tal area of Poland }\end{array}$ \\
\hline & & $\begin{array}{c}3,444.80 \\
\text { (surface waters) }\end{array}$ & 1.10 \\
\hline Poor & 8 & $37,073.50$ & 11.88 \\
\hline Medium & 13 & $93,047.85$ & 29.82 \\
\hline Good & 20 & $74,096.07$ & 23.74 \\
\hline Very good & 27 & $104,421.81$ & 33.46 \\
\hline & Total area & $312,075.04$ & 100 \\
\hline
\end{tabular}

obtained for particular calculated fields ranged from 42 to $229.5 \mathrm{~mm}$. Figure 4 shows the results of these calculations in the form of a groundwater recharge map where each colour represents a different 25 millimetre bracket.

Based on the constructed map, the total groundwater recharge from precipitation in Poland was calculated at $34.118 \mathrm{~km}^{3}$ per year, which equals $109.3 \mathrm{~mm}$ of water column. The recharge constituted $18.6 \%$ of average precipitation in Poland, which was calculated at $588.5 \mathrm{~mm}$. This value does not differ much from the other sources (Jokiel, 1994; Duda et al., 2011). In the framework of the map of groundwater vulnerability to pollution in Poland 1:500,000, the total groundwater recharge was estimated at $31.515 \mathrm{~km}^{3} /$ year, which equals $102.2 \mathrm{~mm}$ (Duda et al., 2011).

In the third stage the resultant map of groundwater recharge was verified for areas of chosen river basins in Poland. Detailed calculations were made for 22 river basins (test area - stage III; Fig. 3) with known discharge rates in the years 1976-2005. The authors tried to verify the precision of the estimation of the recharge based on earlier 15 test river basins (test area - stage II). The recharge values obtained for 22 basins from the test area has been compared with the values of the groundwater runoff adequate to the catchment. Differences in the values of groundwater runoff and calculated recharge vary from 0.07 to $5.15 \mathrm{~m}^{3} / \mathrm{s}$, at the mean value $-0.18 \mathrm{~m}^{3} / \mathrm{s}$. This dependence shows similar differentiation as in the test area - stage II (Fig. 5).

In relation to the groundwater runoff, the absolute value of the difference between groundwater runoff and recharge (AV) ranges from 0.4 to $80.65 \%$ (Table 5), at the arithmetic mean $36.18 \%$ and the geometric mean $23.39 \%$. In this way for 22 test river basins (test area - stage III) it is obtained the greater compatibility between the groundwater runoff and the calculated recharge than for the test area, where the average value of the deviation was $40.90 \%$ and the geometrical mean $28.46 \%$. This confirms that constructed map of infiltration is respectable for the estimation of the groundwater recharge when evaluating in a small scale. The calculated effective infiltration values are higher that the measured values of the groundwater runoff in 10 cases. These are basins located in the upper courses of rivers, which 


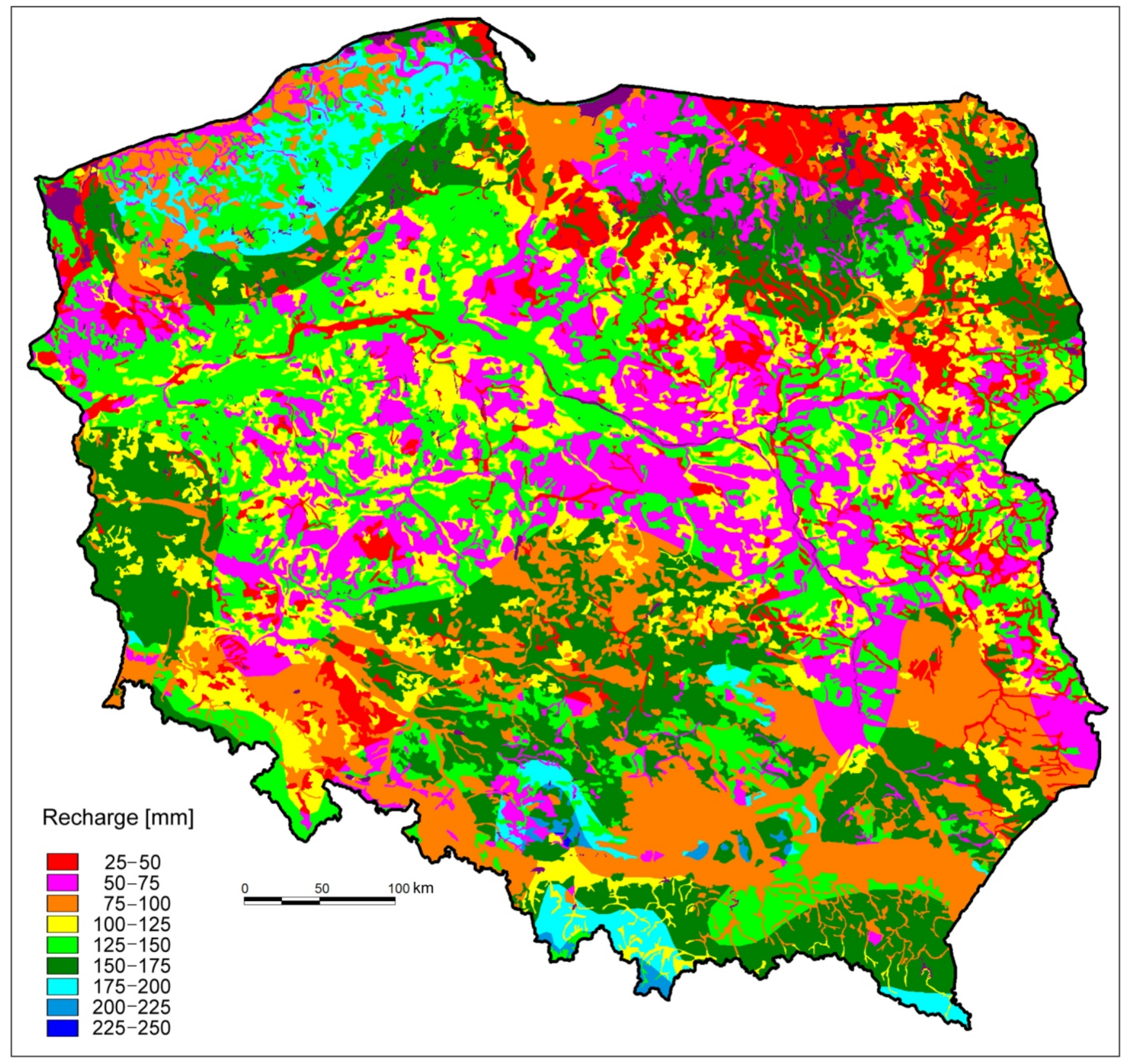

Fig. 4. Map of groundwater recharge in Poland, based on the infiltration coefficient method

could be explained by the prevalence of the deeper component of the water circulation (recharge area) in this part of the system. In catchments situated in lower river course according to the flow systems theory appear the aggregated groundwater resources. This explains why the calculated values are lower than the measured ones in this case. The final results for all the 37 river basins (test areas - stages II and III) are presented in Table 6.

As a consequence, in larger catchments with high values of reported runoff the discrepancies between evaluated recharge rates could be larger. Due to the size of the deviation of the calculated recharge and groundwater runoff reference to the magnitude of the catchment obtaining the specific difference (SD). In the test area -stage II (22 river basins), the specific difference varies from -3.48 to $2.54 \mathrm{l} / \mathrm{s} \mathrm{km}^{2}$ (Table 6), at the arithmetic mean $0.04 \mathrm{l} / \mathrm{s} \mathrm{km}^{2}$. Analysis of Figure 6 shows that specific differences have a similar value regardless of the area of the river basin. For the $70 \%$ of all 37 analysed catch- ments this value is lower from $1.5 \mathrm{l} / \mathrm{s} \mathrm{km}^{2}$. There is a lack of clear relationship between the specific difference and the groundwater runoff (Fig. 6).

\section{GROUNWATER RECHARGE ESTIMATION}

The groundwater recharge values for 22 river basins (test area - stage III) range from $93.1 \mathrm{~mm}$ (Ina River basin) to $179.3 \mathrm{~mm}$ (Skawa River basin) in the Carpathians. The average groundwater recharge was calculated at $125.7 \mathrm{~mm}$, while the figure obtained through groundwater runoff was $129.6 \mathrm{~mm}$ (Table 5).

The average value of recharge rate for all 37 river basins (total area over $50,000 \mathrm{~km}^{2}$ ) is $120.5 \mathrm{~mm}$. The mean value of the infiltration coefficient is $19.73 \%$. 


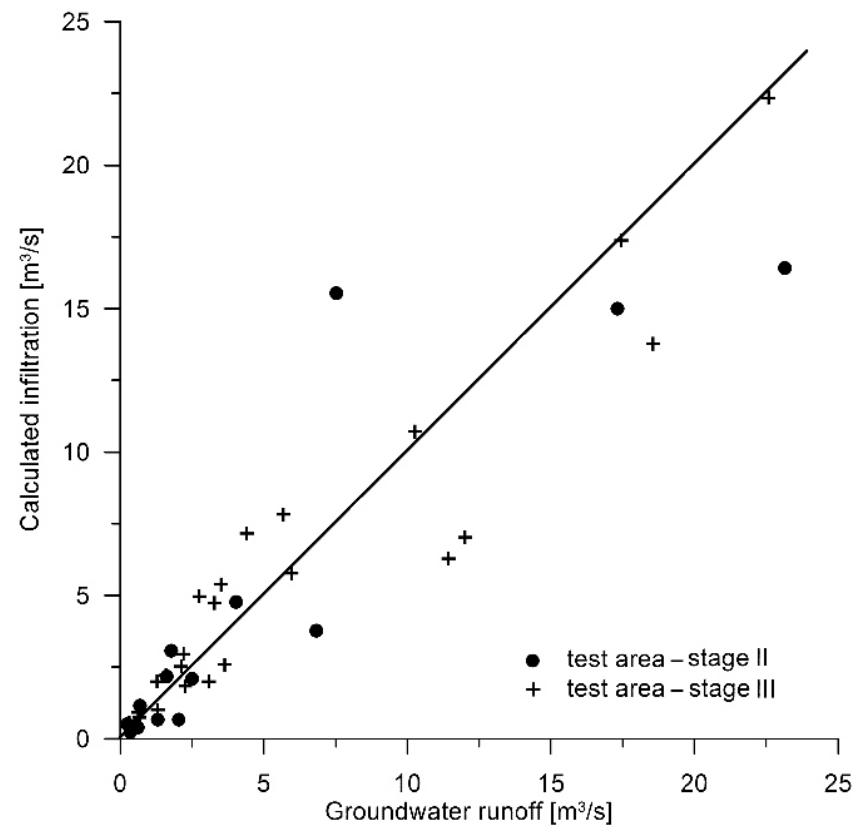

Fig. 5. The relationship between calculated infiltration (infiltration coeficient method) and groundwater runoff (Wundt method)
The results show conformity with research results in other countries. For example, lysimeter measurements of river and lake sediments show the wide range of the value from 1 to $3000 \mathrm{~mm} /$ year in Minnesota and Wisconsin, and from 12 to $122 \mathrm{~mm} /$ year in Nevada (vide Scanlon et al., 2002). Using the hydrograph separation method obtained recharge value from 127 to $635 \mathrm{~mm} /$ year for rivers basins of the eastern USA (Rutledge 1998, vide Scanlon et al., 2002). Uddameri and Kuchanur (2006), in turn, applying the modelling of the water balance show low magnitudes of the recharge in south Texas within the range from 0 to $15.2 \mathrm{~mm} /$ year. Applying isotope technique (tritium injection) it has been reported at the foot of the $\mathrm{Hi}-$ malayas that within a period of monsoonal rains the range of the infiltration 3-13\% of precipitation (Israil et al., 2006). Research of recharge in India performed by means of indicatory methods showed values from $3-10 \%(20-50 \mathrm{~mm})$ of annual precipitation in the Western Rajasthan to 12-20\% (120-200 mm) in Uttar Pradesh, Punjab, and Haryana (Sukhija et al., 1996). The coastal areas of Pondicherry and Neyveli have an average recharge rate of about $15-25 \%(200-300 \mathrm{~mm})$. In the basaltic and granitic-gneissic rocks the natural recharge rate has been evaluated as $3-15 \%(20-100 \mathrm{~mm})$. In the Germany and the Netherlands with similar climatic conditions like in Poland, the groundwater recharge is $135 \mathrm{~mm}$ to average annual precipitation equal 859 mm (Zingk, 1988; Otto, 2001).

Additionally, results of the calculation have been compared with published data from numerical modelling evaluation and selected data published from Poland, Germany, USA, India and

Comparison of infiltration values and groundwater runoff in the test area - stage III

\begin{tabular}{|c|c|c|c|c|c|c|c|}
\hline No. & River & Gauge & $\begin{array}{c}\text { Calculated } \\
\text { infiltration } \\
{\left[\mathrm{m}^{3} / \mathrm{s}\right]}\end{array}$ & $\begin{array}{c}\text { Groundwater } \\
\text { runoff } \\
{\left[\mathrm{m}^{3} / \mathrm{s}\right]}\end{array}$ & $\begin{array}{c}\text { Absolute } \\
\text { variability } \\
{[\%]}\end{array}$ & $\begin{array}{c}\text { Specific } \\
\text { difference } \\
{\left[\mathrm{l} / \mathrm{s} \cdot \mathrm{km}^{2}\right]}\end{array}$ & $\begin{array}{c}\text { Infiltration } \\
\text { coefficient } \\
{[\%]}\end{array}$ \\
\hline 16 & Gwda & Piła & 22.34 & 22.58 & 1.1 & -0.05 & 24.8 \\
\hline 17 & Drawa & Drawsko Pomorskie & 2.59 & 3.64 & 28.8 & -1.72 & 19.9 \\
\hline 18 & Ina & Goleniów & 6.28 & 11.43 & 45.1 & -2.42 & 16.2 \\
\hline 19 & Słupia & Słupsk & 7.03 & 12 & 41.4 & -3.48 & 23 \\
\hline 20 & Warta & Działoszyn & 17.38 & 17.45 & 0.4 & -0.02 & 22 \\
\hline 21 & Prosna & Mirków & 4.97 & 2.75 & 80.7 & 1.78 & 21.7 \\
\hline 22 & Noteć & Pakość & 7.16 & 4.41 & 62.4 & 1.26 & 19.8 \\
\hline 23 & Reda & Wejherowo & 2 & 3.09 & 35.3 & -2.77 & 23.9 \\
\hline 24 & Bukowa & Ruda Jastkowska & 2.97 & 2.2 & 35.0 & 1.18 & 24.8 \\
\hline 25 & Pisa & Ptaki & 13.77 & 18.55 & 25.8 & -1.34 & 19.8 \\
\hline 26 & Liwiec & Lochów & 7.82 & 5.68 & 37.7 & 0.87 & 19.1 \\
\hline 27 & Biała & Grybów & 0.92 & 0.62 & 48.4 & 1.46 & 19.2 \\
\hline $\begin{array}{l}\text { faul } \\
\text { t28 }\end{array}$ & Skawa & Jordanów & 0.56 & 0.31 & 80.6 & 2.54 & 18.9 \\
\hline 29 & Łososina & Piekiełko & 0.74 & 0.66 & 12.1 & 0.52 & 18.5 \\
\hline 30 & Skrwa & Parzeńn & 5.39 & 3.51 & 53.6 & 1.21 & 20.9 \\
\hline 31 & Kamienica & Nowy Sącz & 1.01 & 1.3 & 22.3 & -1.22 & 19.3 \\
\hline 32 & Świder & Wólka Młądzka & 2.53 & 2.11 & 19.9 & 0.50 & 18.2 \\
\hline 33 & Orzyc & Krasnosielsk & 4.74 & 3.28 & 44.5 & 1.14 & 20.6 \\
\hline 34 & Brzozówka & Karpowicze & 2.22 & 1.58 & 40.5 & 0.98 & 18.7 \\
\hline 35 & Nurzec & Boćki & 2 & 1.27 & 57.5 & 1.34 & 22 \\
\hline 36 & Wierzyca & Bożepole & 1.84 & 2.26 & 18.6 & -1.04 & 24.3 \\
\hline 37 & Pilica & Przedbórz & 10.71 & 10.26 & 4.4 & 0.18 & 22.7 \\
\hline & Groundwater recharge [mm] & 125.7 & 129.6 & & & \\
\hline
\end{tabular}


Table 6

Statistical data of infiltration and groundwater runoff values in 37 chosen river basins

\begin{tabular}{|l|c|c|c|c|c|c|}
\hline & $\begin{array}{c}\text { Groundwater } \\
\text { runoff } \\
{\left[\mathrm{m}^{3} / \mathrm{s}\right]}\end{array}$ & $\begin{array}{c}\text { Calculated } \\
\text { infiltration } \\
{\left[\mathrm{m}^{3} / \mathrm{s}\right]}\end{array}$ & $\begin{array}{c}\text { Difference } \\
{\left[\mathrm{m}^{3} / \mathrm{s}\right]}\end{array}$ & $\begin{array}{c}\text { Absolute } \\
\text { variability } \\
{[\%]}\end{array}$ & $\begin{array}{c}\text { Specific } \\
\text { difference } \\
{\left[\mathrm{l} / \mathrm{s} \cdot \mathrm{km}^{2}\right]}\end{array}$ & $\begin{array}{c}\text { Infiltration } \\
\text { coefficient } \\
{[\%]}\end{array}$ \\
\hline Min. & 0.24 & 0.24 & -6.73 & 0.40 & -3.48 & 11.9 \\
\hline Max. & 23.14 & 22.34 & 8.02 & 116.67 & 2.54 & 24.8 \\
\hline Mean & 5.44 & 5.24 & -0.20 & 40.91 & -0.36 & 19.73 \\
\hline Geometric mean & 2.70 & 2.78 & - & 28.46 & - & 19.53 \\
\hline Standard deviation & 6.46 & 5.70 & 2.49 & 27.09 & 2.09 & 2.75 \\
\hline Mean deviation & 5.02 & 4.43 & 1.60 & 21.00 & 1.61 & 2.06 \\
\hline
\end{tabular}

Ghana (Table 7). Most of the calculated groundwater recharge values with numerical modelling techniques are in the range of $40-150 \mathrm{~mm}(12-25 \%$ of precipitation), especially in the low-lying part of the country (Table 7). The low value in central Poland (Dąbrowski et al., 2007) is associated with the lowest precipitation in the Mazovia region and the marsh zones (Krogulec and Zabłocki, 2015). As indicted in most modelling studies in the northern and central part of the country, the effective infiltration values are in the range of $90-160 \mathrm{~mm}$, with some deviations in the lakelands. Exceptionally high values are reported as $15-43 \%$ of total precipitation for municipal terrains under deep
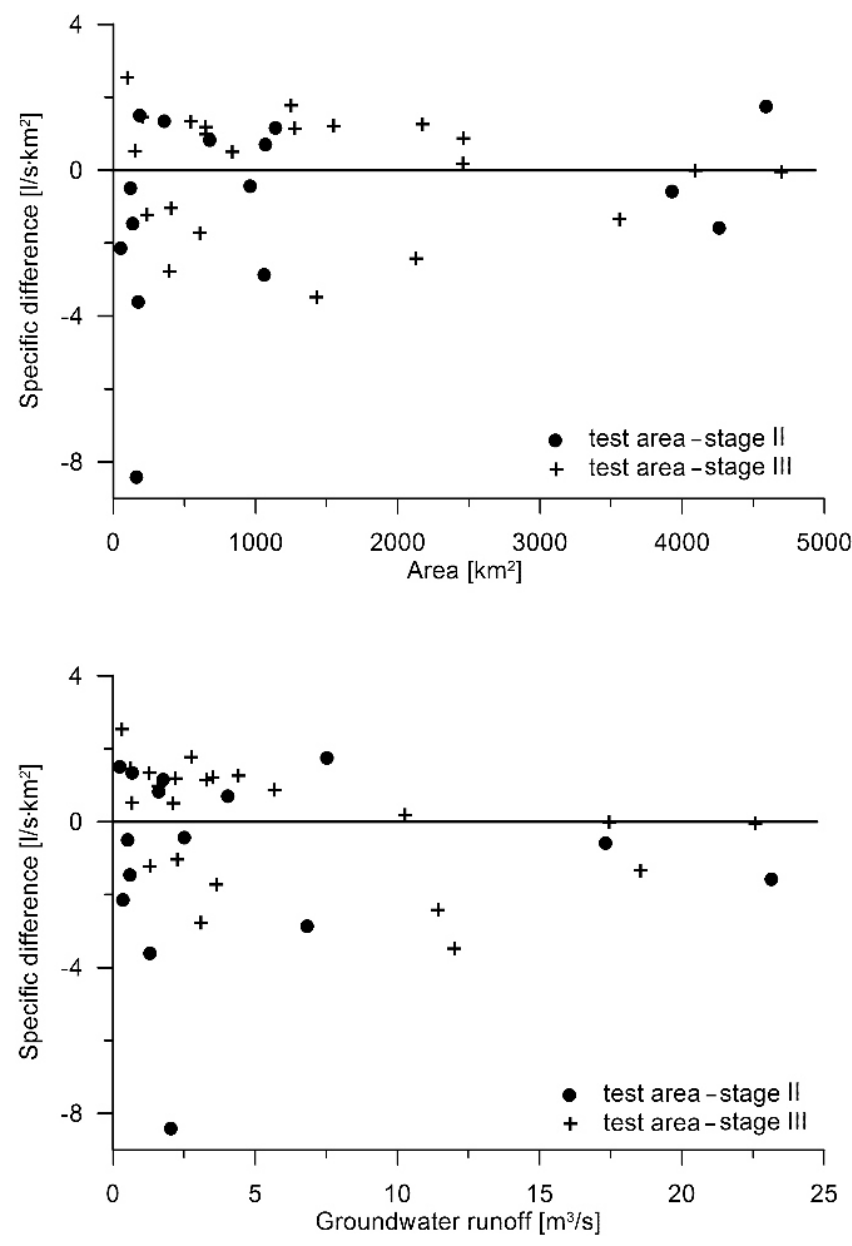

Fig. 6. Illustration of the specific differences between the calculated infiltration and groundwater runoff in 37 chosen river basins mining impact (Kowalczyk, 2005). In the southern uplands and mountainous areas the reported values are $120-265 \mathrm{~mm}$. Evaluation of the groundwater resources also indicates the effective infiltration of $18 \%$ (Herbich and Skrzypczyk, 2015).

\section{CONCLUSIONS}

Due to the high variability of physical and climatic conditions in Poland, many different methods have been employed to assess the groundwater recharge of particular river basins. However, the evaluation of recharge on a smaller scale, such as that of the whole country or large river basins, requires the use of a single method. Applying a modified version of the effective infiltration coefficient method for whole Poland has proven an efficient way of assessing the effective infiltration equivalent to groundwater recharge. The modification of infiltration coefficient values for light soil and forest areas allows a high compatibility of results with groundwater runoff measurements. Results of observations carried out in Lower Silesia and other parts of Poland show groundwater recharge rates ranging from 42 to $229.5 \mathrm{~mm}$, constituting $16.2-24.8 \%$ of total precipitation. Assuming the average precipitation levels in Poland to be around $588.5 \mathrm{~mm}\left(183.43 \mathrm{~km}^{3}\right)$, the groundwater recharge constitutes $18.6 \%$ of precipitation ( $109.3 \mathrm{~mm}$ of water column). Finally, groundwater recharge in Poland after recalculating equals $34.118 \mathrm{~km}^{3}$ per year. The obtained value is close to the average multi-year value of the groundwater runoff (Herbich and Skrzypczyk, 2015). Despite the simplified calculation methods the authors obtained results that are similar to other calculations, which are based on data pertaining to precipitation, soil type, land use, topography of the area, and depth to the groundwater. However, field observations and lysimeter measurements in mountainous areas indicate that, in reality, these figures are much higher and can reach $50 \%$.

This study shows that the application of a simple scheme based on properties of the soil cover and the precipitation distribution are reliable for groundwater recharge evaluation on a small scale. This has also an important practical meaning. Conversely as reported some attempts of the regard in the analysis of the recharge the greater number of factors results not necessary in precise values of this parameter. For example, the map of groundwater vulnerability by Duda et al. (2011) illustrates that arbitrary introduction of the values of land use, topography, and depth to the groundwater did not provide better results. For the same of 22 river basins which are analysed in the cited work the outcomes showed average deviation of the calculated recharge value around $-0.94 \mathrm{~m}^{3} / \mathrm{s}$, so passed five times higher than in the propos method. They also obtained a repeatedly higher value of the individual deviation, amounting to 
Values of the groundwater recharge/infiltration evaluated based on numerical modelling

\begin{tabular}{|c|c|c|c|c|c|}
\hline Location & $\begin{array}{l}\text { Precipitation } \\
{[\mathrm{mm}]}\end{array}$ & $\begin{array}{l}\text { Aquifer: age and type of } \\
\text { rock medium }\end{array}$ & $\begin{array}{l}\text { Recharge } \\
{[\mathrm{mm}]}\end{array}$ & $\begin{array}{c}\text { Infiltration } \\
{[\%]}\end{array}$ & Authors \\
\hline Kaszuby Lake District & 652 & Quatern. sand. gravel & 147 & 22.5 & Jaworska-Szulc (2015) \\
\hline Chełmińskie Lakeland & $500-610$ & Quatern. sand, gravel & $40-90$ & 12 & Pomianowska (1999) \\
\hline Odra River valley & & Quatern. sand, gravel & $52-84$ & 14 & Gurwin (2000) \\
\hline Wisła River valley & 539 & $\begin{array}{l}\text { Quatern. sand, gravel } \\
\text { marsh zones }\end{array}$ & $\begin{array}{c}29-105 \\
50\end{array}$ & $\begin{array}{c}5-19 \\
9\end{array}$ & $\begin{array}{l}\text { Krogulec (2004); } \\
\text { Krogulec and Zabłocki (2015) }\end{array}$ \\
\hline Central Poland & 616 & Quatern. sand, gravel & 37 & 6 & Dąbrowski et al. (2007) \\
\hline $\begin{array}{l}\text { Odra River near } \\
\text { Wrocław }\end{array}$ & 600 & Quatern. sand, gravel & $116-160$ & $19-26$ & Krawczyk et al. (2015) \\
\hline Łódź Basin & 600 & $\begin{array}{l}\text { Cretaceous, sandstone, } \\
\text { limestone }\end{array}$ & 144 & 24 & Rodzoch and Pazio-Urbanowicz (2015) \\
\hline $\begin{array}{l}\text { Carpathian flysch, } \\
\text { Tylicz region }\end{array}$ & 848 & $\begin{array}{l}\text { Paleogene, sandstone, } \\
\text { shale }\end{array}$ & 179 & 21 & Porwisz et al. (1999) \\
\hline $\begin{array}{l}\text { Sudetes Cretaceous } \\
\text { basin }\end{array}$ & 813 & Cretaceous, sandstone & $119-265$ & $15-32$ & Korwin-Piotrowska et al. (2014) \\
\hline Upper Silesia & $779-864$ & Triassicl, imestone & $39-155$ & $5-19$ & Kowalczyk (2005) \\
\hline $\begin{array}{l}\text { Germany } \\
\text { (Schleswig-Holstein } \\
\text { region) }\end{array}$ & 859 & $\begin{array}{c}\text { sand, sandstone, granite } \\
\text { etc. }\end{array}$ & $100-300$ & 16 & Zingk (1988); Otto (2001) \\
\hline $\begin{array}{l}\text { NW India (semi-arid } \\
\text { regions) }\end{array}$ & $500-1000$ & sand, gravel, sandstone & $20-200$ & $3-20$ & Sukhija et al. (1996) \\
\hline USA (eastern states) & $241-1618$ & $\begin{array}{l}\text { sand, sandstone, } \\
\text { limestone, basalt tuff }\end{array}$ & $2.9-191$ & $1-12$ & Rutledge (1998) \\
\hline $\begin{array}{l}\text { North Ghana (tropical } \\
\text { areas) }\end{array}$ & $900-1200$ & $\begin{array}{l}\text { mudstones, siltstones, } \\
\text { sandstones }\end{array}$ & $81-252$ & $0.9-21$ & Menash et al. (2014) \\
\hline
\end{tabular}

$-0.68 \mathrm{l} / \mathrm{s} \mathrm{km}^{2}$. This proves that the accuracy of the average value of groundwater recharge decreases with increasing number of factors influencing the infiltration process.

Acknowledgements. The data presented in this study are a result of observations conducted as part of the statutory research carried out at the Institute of Geological Sciences,
Wrocław University, within the framework of project 1017/S/ING/10, titled "The processes of recharge, flow and drainage of groundwater". The authors express their profound gratitude to all the reviewers (B. Jaworska-Szulc and two anonymous reviewers) for their insightful comments and important suggestions.

\section{REFERENCES}

Ali Rahmani, S.E., Chibane, B., Boucefiène, F., 2016. Groundwater recharge estimation in semi-arid zone: a study case from the region of Djelfa (Algeria). Applied Water Science, 6: 1-11.

Brodie, R.S., Hostetler, S., 2005. A review of techniques for analysing baseflow from stream hydrographs. Bureau of Rural Sciences, Australia. Available via (http://www.connectedwater.gov.au/documents/IAH05_Baseflow.pdf)

Daly, E.P., 1994. Groundwater resources of the Nore River basin. Geological Survey of Ireland, RS 94/1.

Dąbrowski, S., Przybyłek, J., Górski, J., 2007. Subregion Warty Nizinny (in Polish). In: Hydrogeologia Regionalna Polski, tom I, Wody Słodkie (ed. B. Paczyński and A. Sadurski). Państwowy Instytut Geologiczny, Warszawa.

De Vries, J.J., Simmers, I., 2002. Groundwater recharge: an overview of processes and challenges. Hydrogeology Journal, 10: $5-17$.

Duda, R., Zdechlik, R., Paszkiewicz, M., 2006. A few remarks about Raba River watershed mathematical modeling (in Polish with English summary). Geologos, 10: 47-56.

Duda, R., Witczak, S., Żurek, A., 2011. Map of groundwater vulnerability to pollution in Poland, a scale of 1:500,000 - methodology and text explanations (in Polish with English summary). Ministerstwo Środowiska, Warszawa.

Gurwin, J., 2000. Groundwater flow model of the Odra ice-marginal valley aquifer system near Głogów (in Polish with English summary). Prace Geologiczno-Mineralogiczne, 70, Acta Universitatis Wratislaviensis, 2215.

Herbich, P., Nidental, M., Woźnicka, M., 2008. Methodological guidelines of creating GIS Database information layers of Hydrogeological Map of Poland 1:50 000: First Aquifer Groundwater Vulnerability and Water Quality (in Polish with English summary). Współczesne Problemy Hydrogeologii, 13: 253-261.

Herbich, P., Skrzypczyk, L., 2015. The position of fresh groundwater in country's resources management. On some issues about the amount of groundwater resources and the possibilities of their utilisation (in Polish with English summary). Przegląd Geologiczny, 63: 745-749.

Israil, M., Singhal, M.D.C., Kumar, B., 2006. Groundwater-recharge estimation using a surface electrical resistivity method in the Himalayan foothill region, India. Hydrogeology Journal, 14: 44-50. 
Jaworska-Szulc, B., 2015. Groundwater recharge estimation in Kashubian Lake District different scale studies, comparison of methods (in Polish with English summary). Przegląd Geologiczny, 63: 763-768.

Jokiel, P., 1994. Groundwater resources, renewability and runoff in the zone of active exchange in Poland (in Polish with English summary). Acta Geographica Lodziensia, 66-67: 236.

Kondracki J., 1994. Geografia Polski: Mezoregiony fizyczno-geograficzne (in Polish). Wydawnictwo Naukowe PWN, Warszawa.

Korwin-Piotrowska, A., Serafin, R., Wojtkowiak, A., Krawczyk J., Skrzypczyk, L., Zawistowski, K., Chudzik, L., Biel, A., Koros, I., Eckhardt, P., 2014. Groundwater monitoring in the border area of the Sudetes in 2005-2012. Państwowy Instytut Geologiczny, Warszawa.

Kowalczyk, A., 2005. Recharge of groundwater under a human impact based on the example of the Silesian-Cracow Triassic aquifer (in Polish with English summary). Współczesne Problemy Hydrogeologii, 12: 363-370.

Krawczyk, J., Mądrala, D., Horbowy, K., Russ, D., Zawistowski, K., Wojtkowiak, A., Biel, A., 2015. Dokumentacja hydrogeologiczna określająca warunki hydrogeologiczne w zwiazkku z ustanawianiem obszarów ochronnych Głównego Zbiornika Wód Podziemnych nr 320, Pradolina rzeki Odra (S Wrocław) (in Polish). Narodowe Archiwum Geologiczne, Państwowy Instytut Geologiczny, Warszawa, Inw. 2715/2016.

Krogulec, E., 2004. Groundwater recharge - results of modeling research (in Polish with English summary). Acta Universitatis Wratislaviensis, Hydrogeologia, 2729: 121-128.

Krogulec, E., Zabłocki, S., 2015. Relationship between the environmental and hydrogeological elements characterizing groundwater - dependent ecosystems in central Poland. Hydrogeology Journal, 23: 1587-1602.

Lorenc, H., ed., 2005. Atlas klimatu Polski (in Polish). Instytut Meteorologii i Gospodarki Wodnej, Warszawa

Mensah, F.O., Alo, C., Yidana, S.M., 2014. Evaluation of groundwater recharge estimates in a partially metamorphosed sedimentary basin in a tropical environment: Application of natural tracers. The Scientific World Journal, 2014: 1-8.

Otto, R., 2001. Estimating groundwater recharge rates in the southeastern Holstein region, northern Germany. Hydrogeology Journal, 9: 498-511.

Paczyński, B., 1972. Metodyczne zasady oceny zasobów wód podziemnych w strukturach regionalnych (in Polish). Instrukcje i metody badań geologicznych, 17. Wyd. Geol., Warszawa.

Paczyński, B., ed., 1995. Atlas hydrogeologiczny Polski, 1:500 000 (in Polish). Państwowy Instytut Geologiczny, Warszawa.

Paczyński, B., Sadurski, A., eds., 2007. Hydrogeologia Regionalna Polski, tom I, Wody Słodkie. Państwowy Instytut Geologiczny, Warszawa.

Pazdro, Z., Kozerski, B., 1990. Hydrogeologia ogólna (in Polish). Wyd. Geol., Warszawa.

Pleczyński, J., 1981. Odnawialność zasobów wód podziemnych (in Polish). Wyd. Geol., Warszawa.
Pomianowska, H., 1999. Recharge and drainage of groundwater in Chełmińskie Lakeland (in Polish with English summary). Współczesne Problemy Hydrogeologii, 9: 273-279.

Porwisz, B., Radwan, J., Zuber, A., 1999. Groundwater recharge in the Tylicz Region (in Polish with English summary). Współczesne Problemy Hydrogeologii, 9: 287-292.

Rodzoch, A., Pazio-Urbanowicz, K., 2015. Recharge and discharge of groundwater of MGB No. 401 (Łódź Basin) in the light of modelling research (in Polish with English summary). Przeglad Geologiczny, 63: 1037-1041.

Rutledge, A.T., 1998. Computer programs for describing the recession of ground-water discharge and for estimating mean ground-water recharge and discharge from streamflow data update. U.S. Geological Survey Water-Resources Investigations Report, 98-4148.

Scanlon, R.B., Healy, R.W., Cook, P.G., 2002. Choosing appropriate techniques for quantifying groundwater recharge. Hydrogeology Journal, 10: 18-39.

Singh, D.K., 2003. Assessment of groundwater potential. In: Proceedings. Winter School on Advanced Techniques and Their Applications in Water Management (eds. A.K Singh and Manoj Khanna). Water Technology Centre, Indian Agricultural Research Institute, New Delhi: 271-280.

Stankowski, W., 1996. Wstęp do geologii kenozoiku (in Polish). Wydawnictwo Uniwersytet im. Adama Mickiewicza, Poznań.

Staśko, S., Tarka, R., Olichwer, T., 2012. Groundwater recharge evaluation based on the infiltration method. Chapter 16. In Groundwater Quality Sustainability. International Association of Hydrogeology, Selected Papers, 17: 189-197.

Sukhija, B.S., Reddy, D.V., Nagabushanam, P., 1996. Groundwater recharge In semi-arid regions of India: an overview of results obtained using tracers. Hydrogeology Journal, 4: 50-71.

Tarka, R., 2001. Discrepancy in groundwater resources estimation and permeability of the surface zone (in Polish with English summary). Współczesne Problemy Hydrogeologii, 10: 279-287.

Uddameri, V., Kuchanur, Ć.M., 2006. Estimating aquifer recharge in Mission River watershed, Texas: model development and calibration using genetic algorithms. Environmental Geology, 51 897-910.

Voudouris, K., Mavrommatis, Th., Antonakos, A., 2007. Hydrologic balance estimation using GIS in Korinthia prefecture, Greece. Advances in Sciences and Research, 1: 1-8.

Wright, G.R., Aldwell, C. R. Daly, D., Daly, E.P., 1982. Groundwater resources of the Republic of Ireland. European Community's Atlas of Groundwater Resources, 6. SDG, Hanover.

Wundt, W., 1953. Gewasserkunde, Berlin.

Załuski, M., 1973. Groundwater renewability in light of selected data and collated figures (in Polish with English summary). Biuletyn Instytutu Geologicznego, 277: 107-120.

Zingk, M., 1988. Groundwater recharge in Schleswig-Holstein (West-Germany). Agricultural Water Management, 14: 339-343. 